\title{
Intermédialités
}

Histoire et théorie des arts, des lettres et des techniques

Intermediality

History and Theory of the Arts, Literature and Technologies

\section{Masks, Marriage and the Byzantine Mandylion: Classical Inversions in the Tenth Century. Narratio de translatione Constantinopolim imaginis Edessenae}

\section{Glenn A. Peers}

Numéro 8, automne 2006

Envisager

Facing

URI : https://id.erudit.org/iderudit/1005537ar

DOI : https://doi.org/10.7202/1005537ar

Aller au sommaire du numéro

Éditeur(s)

Centre de recherche sur l'intermédialité

ISSN

1705-8546 (imprimé)

1920-3136 (numérique)

Découvrir la revue

Citer cet article

Peers, G. A. (2006). Masks, Marriage and the Byzantine Mandylion: Classical Inversions in the Tenth Century. Narratio de translatione Constantinopolim imaginis Edessenae. Intermédialités / Intermediality, (8), 13-30.

https://doi.org/10.7202/1005537ar
Résumé de l'article

Cet article examine les allusions théâtrales et matrimoniales dans l'hagiographie de la " relique-tactile " du Christ au X $\mathrm{X}^{\mathrm{e}}$ siècle byzantin : le Mandylion. Selon la légende, le Mandylion aurait été créé au moment ou le Christ se serait lavé le visage et qu'une empreinte de son visage se serait ainsi déposée sur le tissu dont il s'était servi pour se sécher. Le Mandylion acquiert une grande popularité a Byzance et dans l'Orient chrétien. Il incarne la protection de Dieu envers son nouveau peuple élu, son immanence dans le monde matériel, et offre une ratification divine de l'art figuratif chrétien. Cet article avance l'hypothèse que l'arrivée du Mandylion a Edesse et son accueil dans la chambre du roi investissent le visage du Christ d'un potentiel puissant d'union avec Dieu. Cette potentialité se trouvait exprimée dans des termes que des Byzantins instruits auraient pu reconnaitre, avec des inversions viscérales du passe classique et du présent chrétien. Elle venait souligner également la légitimité du règne absolu de Constantin VII, par analogie avec le premier roi chrétien, Abgar d'Edesse. 


\title{
Masks, Marriage and the Byzantine Mandylion: Classical Inversions in the Tenth Century
}

\author{
Narratio de translatione Constantinopolim \\ imaginis Edessenae
}

\author{
Glenn A. Peers
}

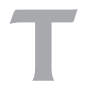

he Mandylion, the most famous East Christian and Byzantine touchrelic of Christ, implicated all levels of devotion, theology and art in the medieval eastern Mediterranean. Believed to have been created when Christ dried his face on a towel, it was a miraculous self-portrait, a deliberate act of surrogation. It recapitulated the Incarnation, it provided divine attendance in its model's wake, and it operated as the paradigmatic moment of artistic practice for medieval Christians. ${ }^{2}$ The relic is now lost, although two medieval copies survive, one in the Vatican and the other at the church of San Bartolomeo degli

1. I would like to express my thanks to colleagues who have been generous in their advice: Anne MacClanan, Judith Herrin and Stephen A. White. Martha Newman and Charles Barber read the essay and gave collegial criticism, but thanks most of all to Herbert Kessler, best skeptic. Unless otherwise noted, all dates are Common Era.

2. The bibliography is vast for this object, and it is growing steadily. Despite the risk of appearing to have neglected that secondary literature, I refer the reader to my Sacred Shock: Framing Visual Experience in Byzantium, University Park, Pennsylvania, Pennsylvania State University Press, 2004, for references to scholarly work that has contributed to this essay. To understand some of the complexities of the Mandylion, I recommend to interested readers works by Georges Didi-Huberman, Devant l'image. Question posée aux fins d'une histoire de l'art, Paris, Éditions de Minuit, coll. "Critique," 1990 (Confronting Images: Questioning the Ends of a Certain History of Art, trans. John Goodman, University Park, Pennsylvania, Pennsylvania State University Press, 2005) and by Marie-José Mondzain, Image, icône, économie: les sources byzantines de l'imaginaire contemporain, Paris, Éditions du Seuil, coll. "L'ordre philosophique," 1996 (Image, Icon, Economy: The Byzantine Origins of the Contemporary Imaginary, trans. Rico Franses, Stanford, Stanford University Press, 2005). 
Armeni in Genoa. (Fig. 1) Last noted in the loot taken to Paris after the taking of Constantinople in 1204, it has always been a mysterious object. It was believed to have been sent by Christ to King Abgar of Edessa (now Urfa in south-eastern Turkey) instead of coming himself; it then was hidden in the city gate there, only uncovered under the assault of a Persian army; venerated by the local population, it was ransomed for prisoners after a Byzantine siege of the city and was taken to Constantinople in 944 with the pomp of an imperial advent; and thereafter it had been a precious relic of the imperial chapel and was seldom seen. The Mandylion was central to a Byzantine understanding of sacred history, for it permitted that culture to capture and to keep proximate a trace of that uniquely "dyophysite" body. And because Byzantine theologians and others had articulated theoretical positions for art during the Iconoclastic debates of the eighth and ninth centuries, a fully intellectualized climate for art theory developed within which a deep and rich tradition for the Mandylion could grow and flourish.

Many scholars have analyzed the iconographic, theological and cultural context for the Mandylion over its long history. In recent years, attention has shifted to examining its traditions in light of our own theoretized views of art and its workings, and it has shown felicitous common ground in conceptual understandings of Byzantine, modern and contemporary art. And yet as a foundation stone of a Christian art history, one might say, the Mandylion resists single and exclusive explanations. It is simply too active an agent in East Christian and Byzantine self-conceptions to be reduced to a single aspect or meaning.

This article attempts to add another dimension to our understanding of Byzantine conceptualizations of that unique self-portrait, and it takes as its starting point an assumption that the face is the site of rich text. ${ }^{3}$ It does not argue for the position taken here as obviating other interpretations. Rather it is one aspect of a prismatic phenomenon, the histories of the Holy Face. For Byzantines, the depiction of that face, accomplished by Christ himself, charged the act of faceto-face in that context with devotional urgency. Here in that space of face before face, Christ and his own creation sought union, found complement and forged new identity. 4

3. See Susan Stewart, On Longing: Narratives of the Miniature, the Gigantic, the Souvenir, the Collection, Baltimore, London, Johns Hopkins University Press, 1984, p. 125-131.

4. While I do not make specific reference to the divergent theories of faciality available, my argument relies on the theoretical attention such work has directed at the face. See Gilles Deleuze and Felix Guattari, Mille plateaux. Capitalisme et schizophrénie 2, Paris, Éditions de Minuit, coll. "Critique," 1980, and Emmanuel Levinas, Totalité et infini, essai sur l'extériorité, La Haye, Martinus Nijhoff, 1961. New theoretical work is clearly needed for this central question in art history. 


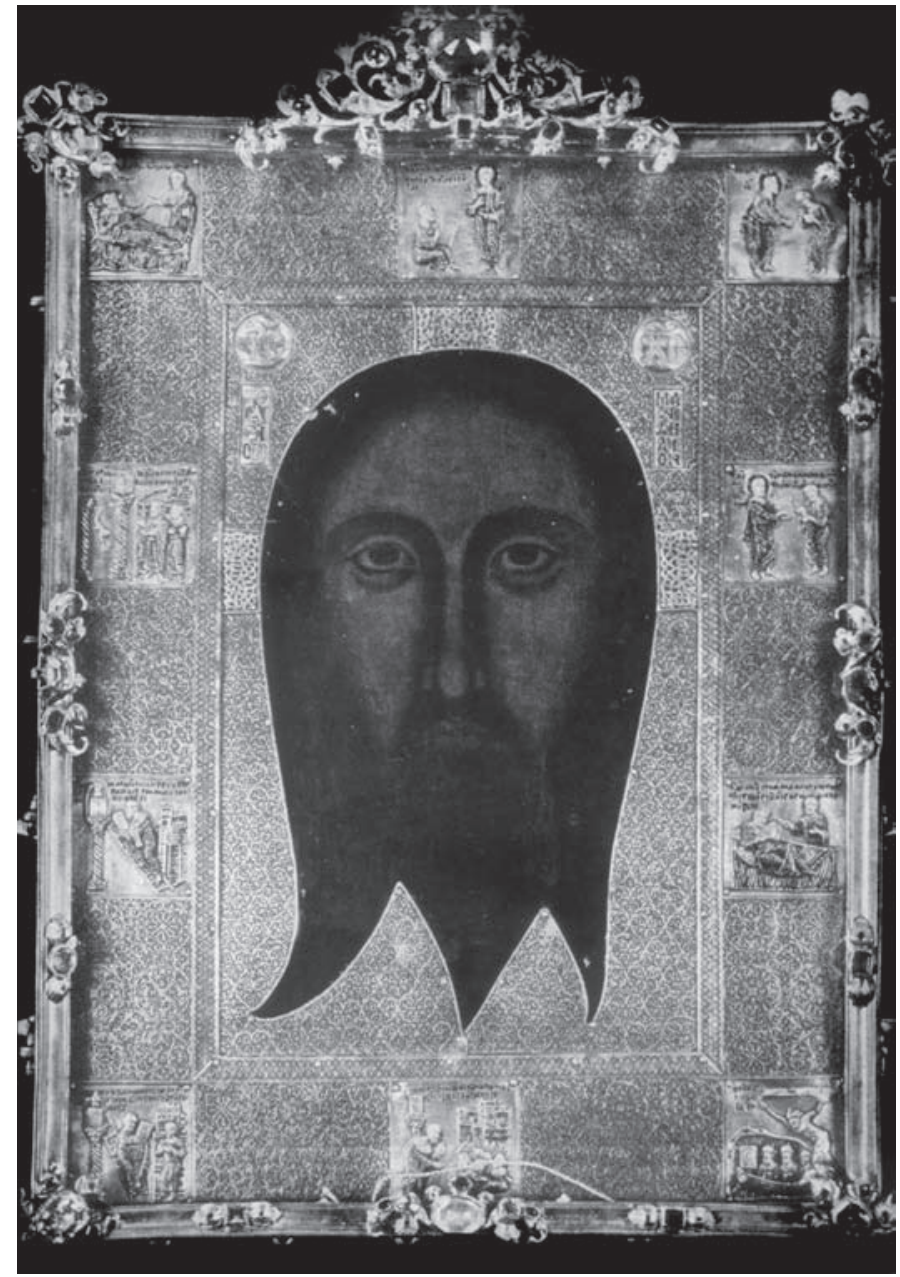

Fig. 1. Mandylion, S. Bartolomeo degli Armeni, Genoa, painting medieval, frame circa 1300 . 
That process just asserted is fundamentally conjugal, in the strict etymological sense of a joining together, an assimilation that is at the heart of Byzantine viewing. In this article, I want to argue for the process being conjugal in the common sense of the word, too. I will make a case for a kind of marriage being inscribed into the understanding of the Mandylion's work. The marriage is not carnal, of course, but spiritual, and yet it does perform itself through the bodies of the participants. In creating a tension between body and spirit, matter and soul, it gives a paradoxical "bodiedness" to transcendent union of Christian to maker. And sexuality plays a role in the description of that union, particularly in the allusions to marriage and in the physical intensity of those allusions.

In order to explore that tension further, I will focus on one text, which is a fully self-aware and highly learned account of the history of the Mandylion from its creation to its arrival at Constantinople in $944 .{ }^{5}$ The text was very likely written by the emperor Constantine VII Porphyrogennetos (r. 945-59, though technically co-emperor from 908), who had a reputation for deep erudition and even artistic abilities. His attachment to the Mandylion was apparently strong, because the icon may have well been the fulcrum he used to gain sole sovereignty of the empire, and he is likely the regal figure holding the Mandylion on the tenth-century icon panel now at the Monastery of St. Catherine at Mount Sinai. (Fig. 2) His learning and his devotion to the Mandylion, however self-interested, have made him the only choice for authorship of the Narratio, but even if he were not directly responsible, the context of energetic scholarship of the Christian and classical past was well established at his court. The circumstances for a sophisticated description of this image-relic were clearly in place, and the Narratio reveals those conditions in the care with which it describes the history of the Mandylion and in the divergences it makes from previous texts. The Narratio shows the direct interventions of the tenth-century writer and audience, for here the rich embellishments are evidence of intellectual and creative readings of a history of Christian faces that took place at the court of Constantine VII.

When he was about to appear before [Abgar], [Thaddaeus] placed that very likeness [empherian] on his own forehead and so came before Abgar. Seeing him coming in from a distance, [Abgar] saw a light shining from his face that no eye could stand, which the portrait Thaddeus was wearing produced. Abgar was dumbfounded by the unbearable glow of the brightness, and, as though forgetting the ailment he had and the long paralysis of his limbs, he at once got up from his bed and compelled himself to run. In making his paralyzed limbs go to meet Thaddeus, he felt the same

5. See Constantine Porphyrogennetos, Narratio de translatione Constantinopolim imaginis Edessenae, in Patrologiae cursus completes. Series graeca, Jacques-Paul Migne (ed.), 161 vols. in 166 pts., Paris, Migne, 1857-66, vol. 113, cols. 421-454. 
MASKS, MARRIAGE AND THE BYZANTINE MANDYLION

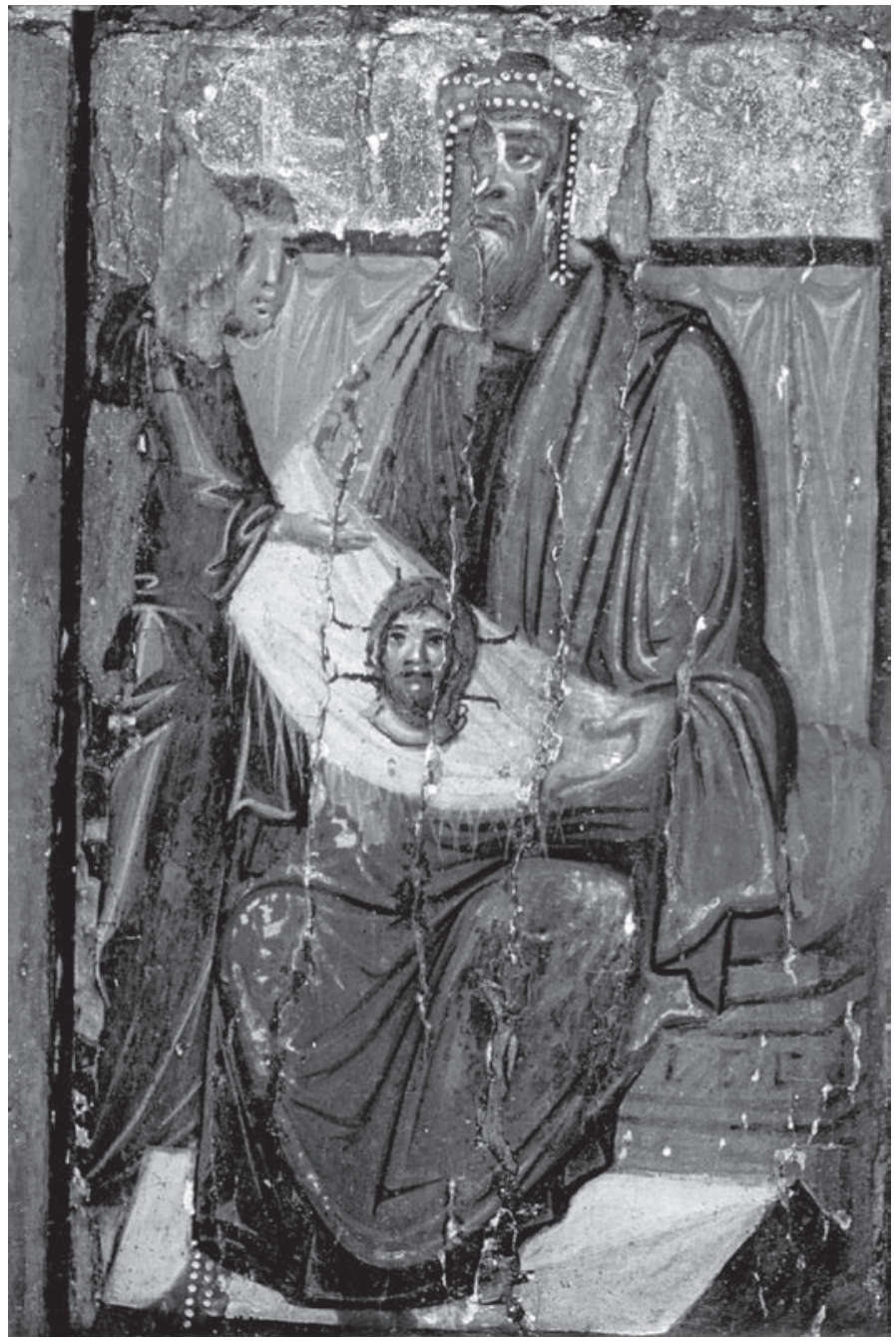

Fig. 2. Icon of Thaddeus, King Abgar and Four Saints, Monastery of St. Catherine, Mount Sinai, tenth century. 


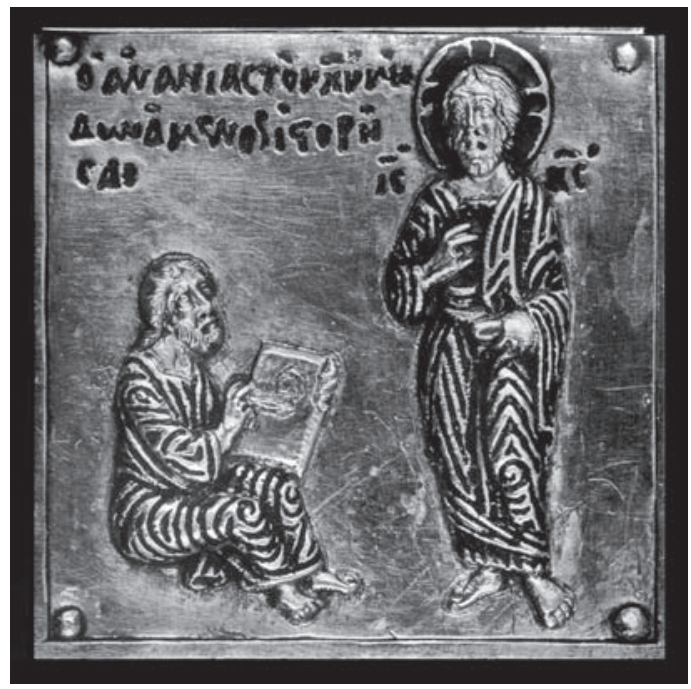

Fig. 3. Detail of Frame of Mandylion, S. Bartolomeo degli Armeni, Genoa, circa 1300.

feeling, though in a different way, as those who saw that face flashing with lightning on Mount Tabor. And so, receiving the likeness from the apostle and placing it reverently on his [Abgar's] head, and applying it to his lips, and not depriving the rest of the parts of his body of such a touch, immediately he felt all the parts of his body being marvelously strengthened and taking a turn for the better; his leprosy cleansed and gone, but a trace of it still remained on his forehead. ${ }^{6}$

The Narratio described the key moments of the history of the Mandylion's creation that were based on earlier versions, but also developed certain motifs in a way not found in previous versions. The king of Edessa, Abgar, sent a messenger to Christ in Jerusalem, and he asked that Christ come to his kingdom to escape his persecutions. Christ naturally refused, but as recompense, he sent to Abgar a letter and a portrait.7 The portraitist sent by Abgar had been unable to fulfill his

6. Narratio, 12-13, cols. $433 \mathrm{C}-436 \mathrm{~A}$. A translation can be found in Ian Wilson, The Shroud of Turin: The Burial Cloth of Jesus Christ?, Garden City, New York, Doubleday, 1978 , p. 235-251, here adapted from p. 241. This last reference raises the quasi-historical issue of the Shroud of Turin. For a scholarly treatment of the Shroud, with further bibliography, see Alan Friedlander, "On the Provenance of the Holy Shroud of Lirey/Turin: A Minor Suggestion," Journal of Ecclesiastical History, Vol. 57, No. 3, July 2006, p. 457-477.

7. On the letter, see my forthcoming "Magic, the Mandylion and the Letter of Abgar: A Fourteenth-Century Amulet Roll in Chicago and New York," in Gerhard Wolf, Colette Dufour Bozzo, Anna Rosa Calderoni Masetti (eds.), Intorno al Sacro Volto: Genova, Bisanzio e il Mediterraneo (XI-XIV secolo), Genova, [forthcoming]. 


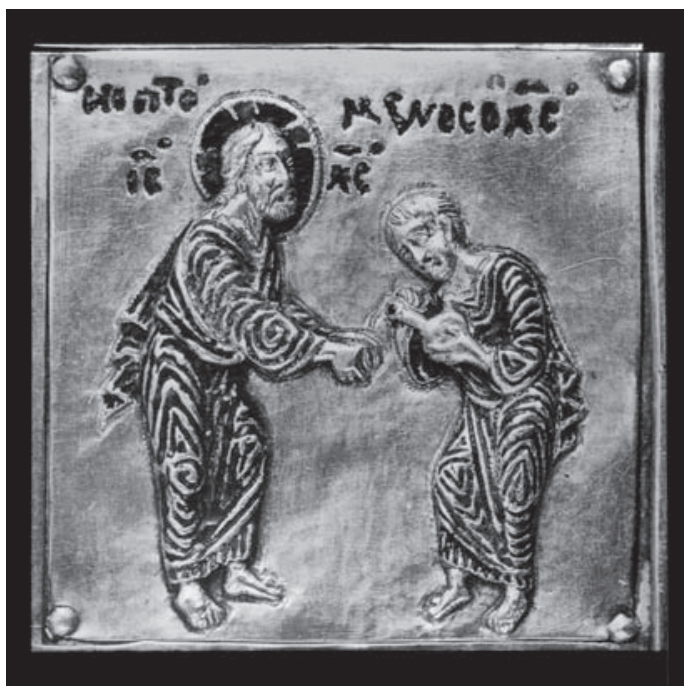

Fig. 4. Detail of Frame of Mandylion, S. Bartolomeo degli Armeni, Genoa, circa 1300.

brief, as Christ escaped the normal means of portraiture. Christ then asked to wash his face, and on the towel with which he dried it, he left a direct impression of his face. (Figs. 3-4) This miraculous object traveled to Edessa in the hands of the apostle promised by Christ, Thaddeus or Addai. I will focus specifically on the moment of encounter among faces, when Thaddeus brings the Mandylion before Abgar, for the encounter was a carefully framed passage that described faces covered and uncovered, meeting and melding, in ways intended to be read, on one level, as Christian narrative but on another, complex level, as a marriage, a wedding inverted in order to give dramatic force to conversion to Christianity and union with God.

In the first place, this moment is a theatrical encounter among faces. Thaddeus has arrived in Edessa after an eventful journey north from Jerusalem, and he is apparently able to walk into the king's chamber unannounced. Before he enters, he puts the face of Christ over his own, and Abgar sees a shining mask in the place of a normal face. That moment is clearly indebted to earlier texts for its stage setting, and the Transfiguration on Tabor is the debt acknowledged overtly in the text. ${ }^{8}$ On one level, that reference signals the transformed nature of the apostle to the Edessans, a man literally divinized by wearing another face. The unbearable quality of that vision, moreover, refers to the meeting of God on Sinai by Moses and the unviewable face of Moses when he descends from the Mount.

8. Matthew, 17:1-13, Mark, 9:2-13, Luke, 9:28-36. 
Moses, however, needed to cover his face with a veil in order for his person to be approached, whereas Thaddeus performed the opposite act in assuming the brilliant mask: his glowing face faced out.

The theatricality of the encounter was also underlined by Abgar's reaction. Abgar dashed across the room-stage seems better, when reading the fashioning of this textual passage-from his sickbed to embrace the image. The theatricality of the entrance, that is before the mask of Thaddeus becomes Abgar's mirror of the beloved, needs to be taken literally, I believe. Resonance of theatrical performances is present in the setting of the Narratio's scene. Wearing masks were part of theatrical performances in the ancient world, naturally, but also in Byzantium, and mask-wearing performers were not uncommon in the Great Palace at Constantinople. ${ }^{9}$

Thaddeus stops at the threshold of the room, stage right one might imagine, and Abgar goes to him. Pausing at the threshold, the apostle was revealing God's imminence in the city through this new sign of his attendance, this mask, veil, likeness. He was bringing, in short, a new Palladium for Edessa. Such uncanny occurrences testify in ancient literature to especially powerful images. When Diomedes and Odysseus took the Palladium from Troy, the image of Athena showed her wrath and revoked her protection of the city, and she did so in no uncertain terms, for her countenance flashed, she sweated and leapt from the ground. ${ }^{10}$ Two implications arise from this general comparison between the Mandylion and Troy's Palladium. The first is the nature of classical allusion embedded in a text like this Narratio. Like most Byzantine intellectuals, the author of the Narratio was raised on and nourished by classical literature. One of the accusations often leveled against Byzantine culture is the derivative quality of its own literature, for it is so interlarded with classicisms as to be scarcely more than florilegia. This accusation is a longstanding prejudice, rather than a truly sympathetic evaluation of Byzantine literature. Yet it has a measure of truth, just the same, because Byzantine writers took great delight in the emulation of classical authors and in embedding references and quotations, however loosely

9. Massimo Bernabò, From Comedy to Psalm: Ancient Theatre and Byzantine Illustration of the Psalter, forthcoming supplemental volume of the Bulletin for the Institute of Classical Studies, University of London, 2006, and Eugenia Bolognesi Recchi Franceschini, "The Iron Masks: The Persistence of Pagan Festivals in Christian Byzantium," in Stephanos Efthymiadis, Claudia Rapp and Dimitris Tsougarakis (eds.), Bosphorus: Essays in Honour of Cyril Mango, Byzantinische Forschungen, Vol. 21, Amsterdam, Adolf M. Hakkert, 1995, p. 117-134.

10. Virgil, Aeneid, 2.172-177. See Christopher A. Faraone, Talismans and Trojan Horses: Guardian Statues in Ancient Greek Myth and Ritual, New York, London, Oxford University Press, 1992. 
remembered, in their texts. ${ }^{11}$ In that sense, Byzantine literature can only be read with an understanding of the classical literature that preceded it, but it cannot be appreciated without understanding that those earlier texts were read and used for a purpose. That purpose is often not what we would expect. For instance, the patriarch Photius (circa 810-after 893) wrote a long set of prose summaries of works he had read, and noteworthy was his reading of Herodotus (484-circa 425 B.C.E.), who had not been writing of the valiant Greek city states against the Persians, as it is normally for us, but rather-in Photius's reading-of unlawful revolt against a monarch. ${ }^{12}$ The second, then, is the meaning of classical allusion here in the Narratio. The passage may not be making specific allusion to the Aeneid, but other examples could also be produced from classical literature, and noteworthy is the way in which the brilliant mask/shining self-portrait makes its homecoming known, through a kind of animation that elicits the melodramatic sprint of Abgar. The Mandylion showed it was home at the threshold, where apotropaic masks were often displayed, and it revealed its protective energy in its transformation of Abgar's illness. It manifested its new identity as palladium of Edessa, for the story later told of its role in repelling the Persians later, and this identity remained no less urgent when it came to Constantinople. In fact, that role was well developed by the time the Mandylion arrived in the Capitol, and the Narratio only served to underline its prowess as palladium by its inversion of such stories as Athena's forsaking her city and her travel with Aeneas to Rome. New Rome on the Bosphoros had its own, truer palladium, as the Narratio revealed to attentive readers of that passage.

If the entrance of the gleaming mask can be understood as the entry of the new palladium to Edessa, standing in for Constantinople here, it is also a moment of intense yearning and satiation of desire. (Fig. 5) Abgar got up from his bed and ran headlong at the shining apparition in the doorway; he embraced the image like a desperate lover who had given up hope of seeing his beloved. The face worn by Thaddeus is still a face when taken by Abgar, and the king takes that face and puts it on his own, inwardly faced one assumes, as he kisses and caresses it. The melodramatic appearance of the apostle approximates the sentimentality of an unexpectedly returning lover who arrives just in time to witness the passing of a beloved one. Acknowledgement and subversion of such conventions of

11. On this question, see Antony R. Littlewood, "The Byzantine Letter of Consolation in the Macedonian and Komnenian Periods," Dumbarton Oaks Papers, No. 53, 1999, p. 19-41, and also Antony R. Littlewood, "Literature," in Jonathan Harris (ed.), Palgrave Advances in Byzantine History, Houndmills, Basingstoke, Hampshire, New York, Palgrave Macmillan, 2005, p. 133-146.

12. Photius, Bibliothèque, 8 vols., René Henry (ed.), Paris, Éditions Les Belles Lettres, 1959-77, vol. I, p. 57-58. 
ancient drama and novels were at the heart of how this passage from the Narratio was intended to work in the eyes of a sensitive reader.

Another level of allusion was at work in this passage, and it drew on stories of reunions of lovers in which images played a central role. Such stories were a topos of ancient literature, for example, Laodamia who showed so much longing for the portrait of her dead husband, Protesilaos, that the gods temporarily released him from Hades. When he was taken back to Hades, Laodamia killed herself. The story was sometimes depicted in Roman art, and it was known to medieval Greek readers, too. ${ }^{13}$ But this story was not the only one available that shared the motifs of portraits and returned lovers, and the passage in the Narratio belongs to this genre rather than simply being a later adaptation of that type of image-filled tale of longing and loss. On the one hand, the Narratio passage gains strength from the very inversion of that genre; it refers to it on some level, but it also subverts the hopelessness of those earlier stories with its consummated longing in conversion and healing. On the other hand, the tension between the spiritual longing of Abgar and his physical expression of that desire creates a high degree of bodiedness in this story. Having been impersonated by Thaddeus, Christ becomes the returned lover, like Protesilaos, who also leaves. Yet Abgar could be sated. His body met his savior's body, and it was transformed, healed and Christianized, by that feverish pressing of Christ all over his body.

The face was the site for creating new subjectivities in this passage. Those three bodies - specifically, the faces of Abgar, Thaddeus and Christ-then were instruments of spiritual transfiguration, as the Narratio makes explicit in its reference to Mount Tabor. But it is the very sensuality of that transfiguration that is so striking in this passage. The sexual expression of spiritual transfiguration was inscribed on the bodies present at the coming of the Mandylion to Edessa, and Abgar's new, purified self came from Christ's face pressed to his own and all over his body. Such physical metaphors were vivid means of expressing especially important Christian beliefs of union with God and the divinization of body and soul promised in the Incarnation. ${ }^{14}$ For example, Symeon the New Theologian (949?-1022) used an extremely sensual parable to communicate his ideas about

13. Pseudo-Apollodorus (second century), Epitome, 3.30, Lucian (circa 120after 180), Dialogi Mortuorum, xxiii, and Eustathius of Thessalonike (circa 1115-1195/6), Hom. Il. ii.701, p. 325. See also Paul A. Holloway, "Left Behind: Jesus's Consolation of His Disciples in John 13-17," Zeitschrift für die neutestamentliche Wissenschaft, Vol. 96, No. 1-2, 2005, p. 1-34, and Maurizio Bettini, The Portrait of the Lover, trans. Laura Gibbs, Berkeley, University of California Press, 1999, p. 9-14.

14. On this issue, see Stephen G. Nichols, "Rewriting Marriage in the Middle Ages," Romanic Review, Vol. 79, No. 1, 1988, p. 42-60, especially p. 55-59. 


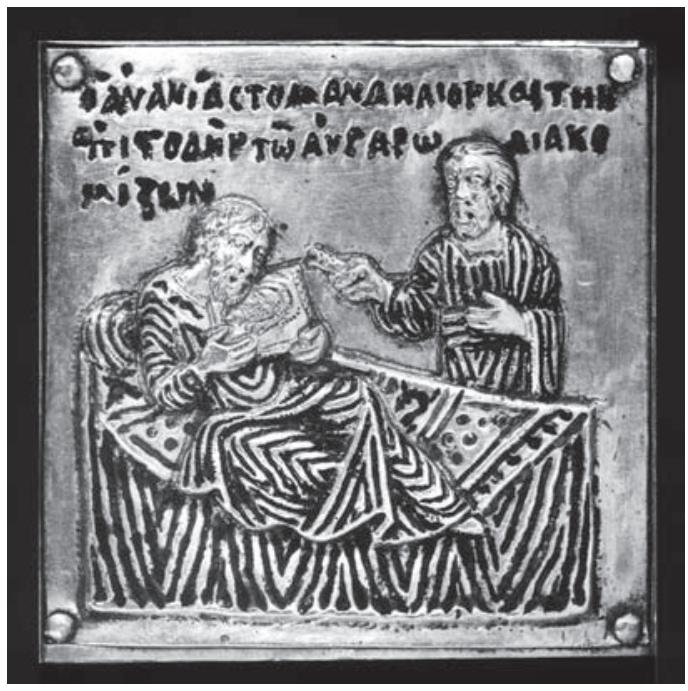

Fig. 5. Detail of Frame of Mandylion, S. Bartolomeo degli Armeni, Genoa, circa 1300.

the necessity of succumbing to God's will. In this parable, an extraordinarily gracious emperor forgave a rebel commander, "So much does he love exceedingly that he is not separated from him even in sleep, but lies together with him embracing him on his bed, and covers him all about with his own cloak, and places his face upon all his members." 15 The insistent invocation of face as the means of transformation is worth noting, for in both the Narratio and in Symeon's parable, face is the point of assimilation, of union of beloveds, where God enters that Christian body, like an infant within the womb. ${ }^{16}$

The scene of encounter of faces was also a wedding, inverted but drawing part of its dramatic power from that reference. The erotic content of this description of union and transformation in the Narratio is like the electric current that

15. Symeon the New Theologian, On the Mystical Life: The Ethical Discourses. Vol. 1: The Church and the Last Things, trans. Alexander Golitzin, Crestwood, New York, St. Vladimir's Seminary Press, 1995, p. 150-151. See Derek Krueger, "Homoerotic Spectacle and the Monastic Body in Symeon the New Theologian," in Virginia Burrus, Catherine Keller (eds.), Toward a Theology of Eros: Transfiguring Passion at the Limits of Discipline, New York, Fordham University Press, 2006, and Virginia Burris, The Sex Lives of Saints: An Erotics of Ancient Hagiography, Philadelphia, University of Pennsylvania Press, 2004.

16. Symeon the New Theologian, On the Mystical Life, p. 169. 
generates light in the story, the luminescence of the mask in the doorway that pulls Abgar off his bed to embrace and caress his just-recognized redeemer. The first glimpse he had was blinding, for the veil worn by Thaddeus hid both the bearer and the impersonated Christ. But when the veil was removed and the beloved discerned, the union occurred that made Abgar Christian. The erotic content was generated also, then, by the heat of an encounter that was very like a marriage. Marriage was naturally a central reality of life in the ancient and medieval worlds, and beyond that banal assertion, it likewise played a key role in imaginings of the relationship between God and humanity, and between God and his creation more generally. Marriage worked as metaphor certainly for Christians when they read passages such as this one:

Thou shalt no more be termed Forsaken [...] for the Lord delighteth in thee, and thy land shall be married. For as a young man marrieth a virgin, so shall thy sons marry thee: and as the bridegroom rejoiceth over the bride, so shall thy God rejoice over thee. ${ }^{17}$

But the passage in the Narratio is even more specific in its manipulation of elements commonly associated with marriage. These elements focused once more on the faces of the threesome at Abgar's palace, and even more specifically on the veiling and unveiling of faces, which was an essential part of marriage in the ancient Greek and Byzantine worlds. ${ }^{18}$ These worlds comprised pagans and Christians, of course, but Jewish practice also used veiling of the bride as a central element in the process of marrying a man and a woman. ${ }^{19}$ The marriage rite in Byzantium has been less fully examined than it has been in the ancient world, but veiling was still a central component, so that that moment of unveiling in the Narratio was likewise recognizable for its audience on that level of experience.

The rite in ancient Greece was the anakalypteria, the uncovering of the face of the bride before her husband. When that moment occurred is not clear from the sources, but the uncovering was inevitably the point at which the bride was made anew, into a wife and mother who has just left girlhood behind. Ancient writers described the anakalypteria as the act of civilization, in fact the very

17. Isaiah, 62:4-5 (King James Version).

18. For Byzantium, see Louis Bréhier, La civilisation byzantine, Paris, Albin Michel, coll. "L'évolution de l'humanité," 1950, p. 8-9, and Phaidon Koukoules, "Symbole eis to peri tou gamou para tois vizantinois kephalaion," Epeteris Hetaireias Byzantinon Spoudon, Vol. 2, 1925, p. 1-41.

19. Molly Myerowitz Levine, "The Gendered Grammar of Ancient Mediterranean Hair," in Wendy Doniger, Howard Eilberg-Schwartz, (eds.), Off with Her Head! The Denial of Women's Identity in Myth, Religion and Culture, Berkeley, University of California Press, 1995, p. 76-130, especially p. 96-102. 
moment when humanity was raised above beasts. They viewed it as the potent act that made order out of chaos. ${ }^{20}$

In the sixth century B.C.E., the philosopher Pherekydes of Syros wrote the most famous passage on the first anakalypteria, in which the veiling and unveiling was not only an act of civilization, but also the formative act of the world. ${ }^{21}$ The work itself does not survive, but Clement of Alexandria (circa 150-circa 215), for one, preserved a passage in his Stromateis, or Miscellanies. Pherekydes described that veiled act of creation in these terms, "Zas [sic] makes a veil [pharos] both big and beautiful, and on it he embroiders Earth and Ogenos, and the places where Ogenos dwells." ${ }^{22}$ This passage survives in Clement, but another papyrus fragment makes clear that Pherekydes was describing the marriage of Zeus and

20. See Lloyd Llewellyn-Jones, Aphrodite's Tortoise: The Veiled Woman of Ancient Greece, Swansea, The Classical Press of Wales, 2003, Gloria Ferrari, Figures of Speech: Men and Maidens in Ancient Greece, Chicago-London, University of Chicago Press, 2002, p. 186-19o, John H. Oakley and Rebecca H. Sinos, The Wedding in Ancient Athens, Madison, University of Wisconsin Press, 1993, Giulia Sissa, Greek Virginity, trans. Arthur Goldhammer, Cambridge, Mass.-London, Harvard University Press, 1990, and John H. Oakley, "The Anakalypteria," Archäologische Anzeiger, Vol. 97, 1982, p. 113-118.

21. Hermann Sadun Schibli, Pherekydes of Syros, Oxford, Clarendon Press, 1990, p. $50-77$.

22. Clément d'Alexandrie, Stromateis, VI.2.9.4. For the text, see Les stromates: Stromate VI, Vol. 446, Patrick Descourtieux (ed.), Paris, Les Éditions du Cerf, coll. "Sources Chrétiennes," 1999, p. 78, 11. 14-16, Hermann Sadun Schibli, Pherekydes of Syros, p. 167, and Hermann Diels, Die Fragmente der Vorsokratiker, 4th ed., 2 vols., Berlin, Weidmannsche Buchhandlung, 1922, vol. II, p. 202. On this passage, see Anne Carson, If Not, Winter: Fragments of Sappho, New York, Alfred A. Knopf, 2002, p. 372; Men in the Off Hours, New York, Alfred A. Knopf, 2000, p. 146, and "Putting Her in Her Place: Woman, Dirt, and Desire," in David M. Halperin, John J. Winkler, and Froma I. Zeitlin (eds.), Before Sexuality: The Construction of Erotic Experience in the Ancient Greek World, Princeton, New Jersey, Princeton University Press, 1990, p. 160-164, as well as John Scheid and Jesper Svenbro, The Craft of Zeus: Myths of Weaving and Fabric, trans. Carol Volk, Cambridge, Massachusetts, London, Harvard University Press, 1996, p. 6365, and Johannes Th. Kakridis, Homer Revisited, Lund, Gleerup, 1971, p. 108-124. Nor was Pherekydes unknown to the Byzantines. I am aware of these occurrences: 1) Diogenes Laërtius (fl. third century), Peri bion dogmaton kai apophthegmaton ton en philosophia eudokimesanton, I.119, who related the story of Pherekydes's cosmogony with Zeus and Ge; 2) Damascius (circa 460-after 538), Aporiai kai lyseis peri ton proton archon, III.2.3, who mentioned the eternal principles of Zas, Chronos and Chthonia; 3) Photius (circa 810-after 893), Bibliothèque, Vol. II, p. 156, 11. 21-2, and at Vol. VIII, p. 179, 11. 5-7, where he mentioned Pherekydes as the author of a genealogy and as a sufferer of a rare disease of the foot; 4) Suidae Lexicon (circa 1000?), Ada Adler (ed.), 5 vols., Leipzig, 1928-38; reprint, Stuttgart, In aedibus B. G. Teubneri, 1967-1971, vol. II, p. 213, 1. 29, vol. IV, p. 262, 1. 17. 
Chthonie, and the first anakalypteria. ${ }^{23}$ For that reason, I translate pharos as veil, when it could also mean mantle or chiton, each of which would also cover the head and conceal the face; in this context, a veil is evidently intended. In the event, the veil signifies three things: the harmony of the cosmos that came from this union, the civilizing effect of marriage connoted in the anakalypteria ceremony, and the craftsmanship of Zeus himself in the fashioning of the veil.

The meeting of Thaddeus and Abgar was an anakalypteria, with Christ as an active third agent in the union effected by the arrival of God's face. In real terms, it stands in for a union of state and faith, as this legend had long represented. ${ }^{24}$ Edessa was a newly Christianized state, the first in the world, if the legend is taken literally. The civilizing effect is naturally part of that union, here too, and from a Byzantine view, harmony of the cosmos was only possible when fully Christianized. More specifically, the process of entry by the veiled apostle, his greeting by an ardent convert, the removal of the veil, and the embrace of convert and the object of his desire are all elements consistent with an anakalypteria. The last act before union of spouses, and their congress, was the removal of the veil, and the first face-to-face meeting was the initiation or recapitulation of cosmic harmony and the foundation of civilized life.

Gender of the participants was not a particular issue, as the parable of Symeon reveals, for the episode of quasi-marriage in Abgar's palace was only meaningful insofar as it expressed union of a corporeal kind. The fact that the Narratio used such visceral language is a sign of the intensity of the moment and of the harmony of body and spirit in this union with God's face. The structures of earlier narratives of anakalypteriai served to give ironic counterpoint to the tenth-century Narratio, to provide a framework familiar on some level to readers and to subvert it with this Christian inversion. In other devotional contexts in Byzantium, veils of icons played an active role, and icons and faces could also meet at the liminal moment of death. ${ }^{25}$

23. Hermann Sadun Schibli, Pherekydes of Syros, p. 165-167.

24. See Alexander Mirkovic, Prelude to Constantine: The Abgar Tradition in Early Christianity, Frankfurt, New York, Peter Lang, 2005.

25. John Zonaras (d. after 1159?), in Epitomae historiarium, XVIII.25.9-14, Corpus scriptorum historiae byzantinae, Vol. 46, Barthold Georg Niebuhr (ed.), Bonn, Weber, 1897, p. 751-752, described the veil of the icon of Christ at Chalke healing the emperor Alexius I (1081-1118). See also Annemarie Weyl Carr, "Threads of Authority: The Virgin Mary's Veil in the Middle Ages," in Steward Gordon (ed.), Robes and Honor: The Medieval World of Investiture, New York, Palgrave, 2001, p. 59-93. On the icon placed on the face of a dying person, see Ernest Alfred Wallis Budge, Saint Michael the Archangel: Three Encomiums, London, K. Paul, Trench, Trubner \& co., 1894, trans. p. 103*, and Lucy-Anne Hunt, "For the Salvation of a Woman's Soul: An Icon of St. Michael Described within a Medieval Coptic Context," in Antony Eastmond, Liz James (eds.), Icon and Word: The 
The role of Zeus as maker likewise corresponds to Christ in his act of selfportraiture. The miraculous impression of face to cloth that led to the revelation of Christ's visage for Abgar was an act of making, naturally, akin to painting. It was distinct, too, for the self-portrait was made without hands, a paradox of fashioning that allowed a relic of Christ's body, which was otherwise impossible. The face denied to the Israelites was shown to Christians, despite the transcendence of that countenance. And it was revealed by God as artist. Unlike Besaleel, who made the Ark of the Covenant by God's specifications (Exodus, 25), the first Christian art was, according to this legend, made by Christ himself, like Zeus who was also the maker of the first art. The metaphor of weaving was heavily invested in Christian writings and beliefs, but Christ was not the maker in the case of weaving. The Holy Spirit could be the weaver when this metaphor was employed. It worked the loom, which was the Virgin Mary, and Christ's flesh was the veil fashioned from this act. ${ }^{26}$

If not specifically a weaver like Zeus, Christ was bodily implicated in processes similar in their cosmic ramifications. Christ himself was in other accounts a craftsman in a related area: dying. Dye was a potent metaphor, too, for it could stand in for the Holy Spirit infiltrating the body of the newly baptized. ${ }^{27}$ And Christ was described in early apocryphal texts as a dyer who performed uncanny feats of craftsmanship..$^{28}$ The cause in Zeus's veil is clear, as the god fashioned

Power of Images in Byzantium. Studies Presented to Robin Cormack, Aldershot, Hants, England, Burlington, Vermont, Ashgate, 2003, p. 210.

26. See Nicholas P. Constas, Proclus of Constantinople and the Cult of the Virgin in Late Antiquity. Homilies 1-5, Texts and Translations, Leiden, Boston, Brill, 2003, p. 315-358, and Maria Evangelatou, "The Purple Thread of the Flesh: The Theological Connotations of a Narrative Iconographic Element in Byzantine Images of the Annunciation," in Antony Eastmond, Liz James, Icon and Word, p. 261-279. See also Barbara Roggema, "Hikayat amthal wa-asmar...: King Parables in Melkite Apologetic Literature," in Rifaat Ebied, Herman Teule (eds.), Studies on the Christian Arabic Heritage: in Honour of Father Prof. Dr. Samir Khalil Samir S.I. at the Occasion of his Sixty-Fifth Birthday, Leuven, Dudley, Massachusetts, Peeters, 2004, p. 113-131.

27. See Régine Charron and Louis Painchaud, "God is a Dyer': The Background and Significance of a Puzzling Motif in the Coptic Gospel According to Philip (CG II, 3)," Le Muséon, Vol. 114, No. 1-2, 2001, p. 41-50.

28. See Edgar Hennecke, New Testament Apocrypha, Wilhelm Schneemelcher (ed.), trans. Robert McLachlan Wilson, 2 vols., Philadelphia, Westminster Press, 196365, vol. I, p. 400-401; Paul Peeters, Évangiles apocryphes. II. L'évangile de l'enfance, Paris, Librairie Alphonse Picard et Fils, 1914, p. 232-246; Walter E. Crum, Catalogue of the Coptic Manuscripts in the Collection of the John Rylands Library, Manchester-London, Manchester University Press, 1909, p. 43-44 [88] and see also Michel Pastoureau, Jésus chez le teinturier. Couleurs et teintures dans l'Occident médiéval, Paris, Éditions du Léopard d'or, 1997. 
it himself, and in this way he also gave cause to the design and order of the universe. ${ }^{29}$ That cause was rationally brought about and understood, and Zeus was distinct from the object he created. The Mandylion was neither, for it was produced in an unprecedented and unreproducible way, and it had the miraculous identity of its maker embedded in its objectness. As a face, a synecdoche for the person, it behaved like that being, with its unworldly ability to reveal its divinity in its strangely glowing appearance, as well as its materiality in its capacity as mask and veil and portrait.

The passage from Pherekydes was not, in all likelihood, a direct model for the writer of the Narratio, but it did exist in several versions. That philosopher was known for his cosmography amongst Byzantines, and such cosmologies were not uncommon for ancient writers generally. $3^{\circ}$ And in any case, the reading of the arrival of the Mandylion in the Edessan palace as an anakalypteria does not rest on a literal reading of the tenth-century text in those terms. Like in the classical world, all mentions of veiling partook of some direct relation to anakalypteria, even if that relation acted through inversion, subversion or irony. ${ }^{31}$ A very striking instance of this process is the death of Demosthenes in 322 B.C.E. as described by Plutarch (45-125), in which Demosthenes veiled his head while he took poison. The guards derided him for his effeminacy, but when Demosthenes felt the poison working, he uncovered himself and confronted his captors. ${ }^{32}$ Odysseus was another heroic figure that assumed a veil during liminal passages in his return home, 33 as Calypso, Nausicaa and Penelope all assumed the veil at significant points in the Odyssey. The contrast between Odysseus's veiling and the "natural" female veiling in the poem gave the hero's act its particular meaning in signaling his transition back to the world of mortals. Other heroes of the ancient

29. Hermann Sadun Schibli, Pherekydes of Syros, p. 56.

30. On the last, see the magisterial overview of Robert Eisler, Weltenmantel und Himmelszelt: Religionsgeschichtliche Untersuchungen zur Urgeschichte des antiken Weltbildes, 2 vols., Munich, CH Beck, 1910.

31. See the studies of Michael N. Nagler, Spontaneity and Tradition: A Study in the Oral Art of Homer, Berkeley, University of California Press, 1974, p. 44-63, and "Towards a Generative View of the Oral Formula," Transactions of the American Philological Association, Vol. 98, 1967, p. 298-307, as well as Lloyd Llewellyn-Jones, Aphrodite's Tortoise, and Douglas L. Cairns, "Anger and the Veil in Ancient Greek Culture," Greece and Rome, Vol. 48, 2001, p. 18-32, and "The Meaning of the Veil in Ancient Greek Culture," in Lloyd Llewellyn-Jones (ed.), Women's Dress in the Ancient World, London, Duckworth Publishing, 2002, p. 73-93.

32. Demosthenes, $29 \cdot 4$.

33. See Dianna Rhyan Kardulias, “Odysseus in Ino's Veil: Feminine Headdress and the Hero in Odyssey 5," Transactions of the American Philological Association, Vol. 131, 2001, p. 23-51. 
world, like Achilles, Ajax, Oedipus and Socrates for example, veiled themselves at critical junctures. Covering the face, and uncovering it too, were potent acts in the Greek world generally that connoted uncertainty, transition, ambivalence, among other meanings.

Multivalent, then, the act of men veiling their faces had a long and wellknown history before the tenth century, and such multivalency was a compelling element for the writer of the Narratio when he needed a way to express indeterminacy of identity amongst Christ, Thaddeus and Abgar, and the transition to a new state by one of the heroes, Abgar. Moreover, the absorption of classical structures of describing transition through veiling was an essential part of the process. Absorbing and subverting classical structures in the story of the Christianization of Edessa was compelling on the grounds of supercession of a pagan past and of demonstrated abilities both to control and undermine the literature of that past. This relationship of Byzantine to classical literature, at once adversarial and indebted, must be recognized in order to appreciate the tension within which many Byzantine authors wrote. The Gospels themselves reveal that debt and demonstrate their divergence simultaneously, and Byzantine literature likewise partook of that Oedipal love. ${ }^{4}$

The passage in the Narratio that described the moment of entry of the face of Christ into a national history is concise in its presentation, but rich and dense in its significances. It represents essential transitions in a Christian history, when the state became reconciled to the message and person of Christ, when ethnic investments in earliest Christian history crystallized, and when each person was granted the ability to assimilate body and soul with the Christian redeemer. ${ }^{35}$ All of these transitions were proleptic, but that reworking of history, and of Greek cultural and literary traditions, was immensely relevant to the tenth-century court at

34. Relevant here is the discussion in Dennis R. MacDonald, The Homeric Epics and the Gospel of Mark, New Haven-London, Yale University Press, 2000, p. 15-19, concerning the Odyssean model for Jesus as carpenter. And I have also tried to argue that classical texts were underlying Byzantine histories of their art, in a similar way to the Mandylion's constructed past, perhaps. See Glenn A. Peers, "The Sosthenion near Constantinople: John Malalas and Ancient Art,” Byzantion, Vol. 68, No. 11, 1998, p. 110-120.

35. For the ideological framework of the Mandylion for Byzantines, see Évelyne Patlagean, "L'entrée de la Sainte Face d'Édesse à Constantinople en 944," in André Vauchez (dir.), La religion civique à l'époque médiévale et moderne (chrétienté et islam), Rome, École française de Rome, Paris, Diffusion de Boccard, 1995, p. 21-35. For the Syriac Christian devotion to Abgar, in particular, see Vincenzo Ruggieri, La Caria bizantina: topografia, archeologia ed arte, Soveria Mannelli, Rubbettino, 2005, p. 165-188, and Karel C. Innemée, Lucas Van Rompay and Elizabeth Sobczynski, "Deir al-Surian (Egypt): Its Wall-paintings, Wall-texts, and Manuscripts," Hugoye, Vol. 2, No. 2, July 1999, http://syrcom.cua.edu/Hugoye/ $\mathrm{Vol}_{2} \mathrm{Noz}_{2} / \mathrm{HV}_{2} \mathrm{~N}_{2} \mathrm{Innemee}$.html. 
Constantinople. Indeed, the recognition of the face of Christ in the Mandylion was a requisite of authority in that context, for Constantine VII used his ability to discern a face in the Mandylion as the sign of legitimacy for taking sole rule of the empire. When he saw that face, his adversaries could not. That privileged vision, paralleling the first Christian king, Abgar, allowed Constantine to move against the sons of Romanos I Lekapenos (r. 920-944) in January 945 and finally gain total control of the throne. The person of Abgar, in his assimilation to Christ through his face-to-face conversion, was a highly potent ideological precedent for Constantine. Correctly understanding face in these instances was a sign of divinely invested kingship, indeed a literal "Mirror of Princes" in that merging of identities that the Narratio so cleverly described. And more broadly even, in centering its attention on the face of Christ, the court committed to its new relic of Christ as a new palladium and as the unveiling of a perfect place in history. 